\title{
Organic Nutrient Management for Improved Plant Growth and Head Yield of Chinese Cabbage (Brassica rapa $L$. var pekinensis)
}

\author{
Sumati Narayan ${ }^{1 *}$, Arief Ibrahim ${ }^{1}$, Farooq Ahmad Khan ${ }^{1}$, Khursheed Hussain ${ }^{1}$, \\ Ajaz Ahmad Malik ${ }^{1}$, Shakeel Ahmad Mir ${ }^{1}$ and Raj Narayan ${ }^{2}$ \\ ${ }^{1}$ Sher-e-Kashmir University of Agricultural Sciences and Technology of Kashmir, Shalimar- \\ 190025, Distt. Srinagar, India \\ ${ }^{2}$ Regional Station (CITH), Mukteshwar, Nainital (UK), India
}

*Corresponding author

\begin{tabular}{|l|}
\hline K e y w o r d s \\
Bio-fertilizers, \\
Chinese cabbage, \\
Organic manures, \\
Plant growth, Yield
\end{tabular}

\section{Introduction}

The importance of leafy vegetables for supply of proteins, vitamins and minerals is well recognized. Chinese cabbage (Brassica rapa L. var pekinensis) is an important leafy, herbaceous vegetable crop originated in China and belongs to the family Crucifereae (Rashid, 1999). It is low in calories, fats and carbohydrates but a good source of minerals, proteins and antioxidants (Singh et al., 2004). There are two major types of Chinese cabbage, the heading and the non-heading. The non- heading type under its most common name Bok Choy is rather open rosette of dark green leaves with white celery like stalks. This plant is more heat tolerant but much more sensitive to cold which makes it bolt when it suddenly turns warm during winter or early spring. The heading types are known as Napa 
cabbage or Michihili. Napa is a short barrelshaped head while the Michihili has a tall cylindrical or tapered head. Neither of these Chinese cabbages look or taste like ordinary cabbage. They both have large cover leaves that are trimmed off to reveal the compact head.

During recent years, Chinese cabbage is gaining popularity in India as potherb, salad as well as cooked vegetable and has become one of the important vegetable crops of eastern India. In $\mathrm{J} \& \mathrm{~K}$, Chinese cabbage is not so far grown by commercial farmers; however, it is being cultivated by innovative farmers and by agricultural research stations at small scale. With increase in people's preference towards diversified vegetable consumption, Chinese cabbage is gaining immediate attention in the Kashmir valley. However, the production package of Chinese cabbage is not much known in the valley. It requires considerable amount of nutrients for rapid growth in a short period of time and thrives well in a fertile clay loam soil (Islam and Haque, 1992). As such, for getting higher production and quality yield of Chinese cabbage it is necessary to ensure availability of essential nutrient components. Heavy use of inorganic fertilizer not only contaminates the ground and surface water but also disturb the harmony existing among the soil, plant and microbial population (Bahadur et al., 2006). There has also been a growing concern about adverse impacts of pesticides and fertilizers on the environment and on the safety and quality of food. Sole use of organic manures, on the other hand, may not be able to give expected yield potential. The release of nutrients from soil organic matter is controlled by soil micro-organisms. Micro-organisms containing preparations having the capability of mobilize nutritive elements from nonusable to usable form through biological processes is called as biofertilizers. Therefore, an integrated approach by making judicious use of organic matters, bio-fertilizers combined with inorganic sources of nutrients is thought to be a better option for sustaining crop productivity and also maintaining soil health. Various studies indicated that organic manures and bio-fertilizers coupled with inorganic sources increase yield and influence quality attributes in vegetables (Tiwari, 2015). Keeping in view the above facts the present investigation has been carried out to find out the suitable nutrient management practices for enhanced growth and yield attributes of Chinese cabbage.

\section{Materials and Methods}

The present investigation was carried out during Rabi 2014 at Experimental Farm, Division of Vegetable Science, SKUASTKashmir, Shalimar lies between $34 .^{\circ}$ North latitude and $74.89^{\circ}$ East longitude at an altitude of 1587 meters above mean sea level and having temperate climate i.e. characterized by hot summers and very cold winters. The soil of the experimental field was low in available $\mathrm{N}$ and medium in available $\mathrm{P}$ and $\mathrm{K}$. Chinese cabbage variety 'Solan band Chinese sarson' having short barrel-shaped head was used as experimental material. There were $13(1+12)$ treatments comprised of four organic manures namely farmyard manure (FYM), biodynamic compost (BDC), sheep manure (SM) and vermicompost (VC), three types of biofertilizers candidly Azotobacter $(A B)$, phosphorus solublizing bacteria (PSB) and potassium solublizing bacteria (KSB) plus recommended fertilizer dose (RDF - NPK @ 100:50:30 kg/ha) through urea, DAP and MOP as control. The experiment was laid in a randomized complete block design (RCBD) with three replications. Amount of nutrients in the organic manures was calculated on the basis nitrogen equivalence. Bio-fertilizers were applied as seedling root dip treatment (@ $2.5 \%$ ) i.e. $25 \mathrm{ml}$ of each of the bio-fertilizers was added in 1 litre of water and roots of the seedlings were kept for 10 minutes in the 
solution before transplanting in the experimental field. All organic manures and inorganic fertilizers were incorporated in the experimental field at the time of land preparation. Twenty five days old uniform and healthy seedlings were transplanted in well prepared plots with spacing of $45 \mathrm{~cm} \times 30 \mathrm{~cm}$. Plant height, fresh weight, dry weight, shoot/root ratio and relative growth rate (RGR) were measured periodically. Time taken to head initiation, no. of folded and unfolded leaves, head diameter, head length, head weight and head compactness in terms of $\mathrm{Z}$ value were recorded accordingly. Plant relative growth rate (RGR) and head compactness were measured by following the method Hoffmann and Poorter (2002) and Pearson (1931) using equation I and II, respectively.

$$
\mathrm{RGR}=\frac{\ln \left(\mathrm{W}_{2}-\mathrm{W}_{1}\right)}{\mathrm{t}_{2}-\mathrm{t}_{1}}
$$

Whereas $\ln =$ natural logarithm and $\mathrm{w}_{1}$ and $\mathrm{w}_{2}$ are plant weights at corresponding time $t_{1}$ and $\mathrm{t}_{2 .}$.

Head compactness $(\mathrm{Z})=\mathrm{C} / \mathrm{W} 3 \times 100$ (II)

Where, $\mathrm{Z}=$ index of compactness; $\mathrm{C}=$ net weight of head; $\mathrm{W}=$ average of equatorial and polar diameter of head

\section{Results and Discussion}

Data presented in table 1-3 revealed significant differences among different nutrient managements practices with respect to plant height (Table 1), plant dry and fresh weight (Table 2) and shoot-root ratio (Table 3) wherein VC@6.6t/ha $+A B+\mathrm{PSB}+\mathrm{KSB}$ $\left(\mathrm{T}_{4}\right)$ recorded maximum plant height (15.33, $20.30,24.23$, and $30.3 \mathrm{~cm}$ ), fresh weight (36.18, 220.79, 570.66 and $1170.00 \mathrm{~g} / \mathrm{plant})$, dry weight (1.9, 6.7, 28.9 and 38.3g/plant), shoot-root (S/R) ratio (32.50, 22.06, 18.68 and 16.46) at 15, 30, 45 and 60 DAT, respectively, which was closely related with FYM @ 20t/ha $+A B+\mathrm{PSB}+\mathrm{KSB}\left(\mathrm{T}_{2}\right), \mathrm{SM} @ 16.6 \mathrm{t} / \mathrm{ha}+A B$ $+\mathrm{PSB}+\mathrm{KSB}\left(\mathrm{T}_{3}\right)$ and BDC @ $8.3 \mathrm{t} / \mathrm{ha}+A B$ $+\mathrm{PSB}+\mathrm{KSB}\left(\mathrm{T}_{5}\right)$ with minor exceptions. In opposition to the maximum values of these parameters in $\mathrm{T}_{4}$, treatment $\mathrm{T}_{6}(50 \% \mathrm{NPK}+$ $50 \%$ FYM) recorded the minimum plant height $(9.66,14.83,19.73$ and $22.63 \mathrm{~cm})$, fresh weight $\quad(16.87, \quad 85.12,184.33 \quad$ and $578.33 \mathrm{~g} /$ plant $)$, dry weight $(1.9,5.9,27.1$ and $31.6 \mathrm{~g} /$ plant $)$ and shoot-root $(\mathrm{S} / \mathrm{R})$ ratio $(17.32$, $12,96,11.79$ and 10.93) at 15, 30, 45 and 60 DAT, respectively which were found to be closely trailed by the recommended dose of sole nutrients through inorganic fertilizers $\left(\mathrm{T}_{1}\right)$.

Perusal of the data presented in table 4 unveiled significant influences of the different sources of nutrients on plant RGR of Chinese cabbage. Among different treatments, $\mathrm{T}_{4}$ (VC@ 6.6t/ha.+ AB+ PSB+ KSB) again recorded maximum RGR value of 0.97 and $0.74 \mathrm{~g} / \mathrm{g} /$ day during $15-30$ and 30-45 DAT and was found statistically at par with $\mathrm{T}_{5}$ (BDC @ $8.3 \mathrm{t} / \mathrm{ha}+A B+\mathrm{PSB}+\mathrm{KSB})$ and $\mathrm{T}_{3}(\mathrm{SM} @$ 16.6t/ha $+A B+\mathrm{PSB}+\mathrm{KSB}$ ) which showed a relative growth rate of $0.94 \mathrm{~g} / \mathrm{g} /$ day and $0.93 \mathrm{~g} / \mathrm{g} /$ day, respectively during $15-30$ and 30-45 DAT. The minimum value of RGR i.e. 0.10 and $0.30 \mathrm{~g} / \mathrm{g} /$ day during 15 to 30 and 30 35 DAT was obtained in $\mathrm{T}_{6}(50 \% \mathrm{NPK}+50 \%$ FYM) which was statistically at par with $\mathrm{T}_{1}$.

The data pertaining to days taken to initiation of head after transplanting (Table 4) notify that $\mathrm{T}_{4}$ (VC @ 6.6t/ha + AB + PSB + KSB) starts early head initiation and took only 19.33 days along with $\mathrm{T}_{2}$ (FYM @ 20t/ha $+A B+$ $\mathrm{PSB}+\mathrm{KSB}), \mathrm{T}_{3}(\mathrm{SM} @ 16.6 \mathrm{t} / \mathrm{ha}+A B+\mathrm{PSB}$ $+\mathrm{KSB})$ and $\mathrm{T}_{5}$ (BDC @ $8.3 \mathrm{t} / \mathrm{ha}+A B+\mathrm{PSB}$ $+\mathrm{KSB}$ ) as they have taken 19.66 days to initiation of head. Application of recommended doses of nutrients through 
inorganic sources taken longer period (22.33 days) to initiate the head formation in Chinese cabbage. As depicted from table 4 treatment $\mathrm{T}_{4}$ (VC@ 6.6t/ha. + AB +PSB+KSB) recorded maximum number of folded leaves (31.33/plant) followed by $\mathrm{T}_{5}$ (30/plant), $\mathrm{T}_{3}$ (29.66/plant) and $T_{2}$ (29.33/plant) but were found statistically at par with $\mathrm{T}_{4}$. The minimum number of folded leaves (22.67/plant) was obtained with $\mathrm{T}_{6}(50 \%$ $\mathrm{NPK}+50 \%$ FYM) followed by $\mathrm{T}_{7} \& \mathrm{~T}_{10}$ (26.33), $\mathrm{T}_{8}$ and $\mathrm{T}_{9}$ (26.00) while as no. of leaves recorded in $\mathrm{T}_{11}, \mathrm{~T}_{12}$ and $\mathrm{T}_{13}$ were 29.00 and 27.00/plant, respectively.

Like number of folded leaves different treatments also influenced number of unfolded leaves plant ${ }^{-1}$ (Table 4) significantly. Among different treatments, treatment $\mathrm{T}_{4}(\mathrm{VC}(\mathrm{VC}) @$ $6.6 \mathrm{t} / \mathrm{ha}+A B+\mathrm{PSB}+\mathrm{KSB})$ resulted a significant increase in number of unfolded leaves (16.33 per plant) and was found superior to all other treatments followed by $\mathrm{T}_{5}$ $(\mathrm{BDC} @ 8.3 \mathrm{t} / \mathrm{ha}+A B+\mathrm{PSB}+\mathrm{KSB})$ $(13.00 \mathrm{~cm})$ and $T_{2}$. The minimum number of unfolded leaves of 09.00/plant were observed in control (treatment $\left.\mathrm{T}_{1}\right)$ and $\mathrm{T}_{6}(50 \% \mathrm{NPK}+$ $50 \% \mathrm{FYM})$. While as $\mathrm{T}_{11}(50 \% \mathrm{NPK}+50 \%$ $(\mathrm{VC})+A B+\mathrm{PSB}+\mathrm{KSB})$ and $\mathrm{T}_{13}(50 \%$ $\mathrm{NPK}+50 \% \mathrm{BDC}+A B+\mathrm{PSB}+\mathrm{KSB})$ were at par with each other with 12.66 number of leaves plant $^{-1}$ but significant with $\mathrm{T}_{1}$ (Recommended dose of fertilizers (RDF) i.e NPK @ 100:50:30 kg/ha), T 6 (50\%NPK+ 50\% $\mathrm{FYM})$ and $\mathrm{T}_{8}(50 \% \mathrm{NPK}+50 \% \mathrm{SM}(\mathrm{SM})$. Middling of like treatments also showed significant variation and followed the patterns of exhibited under folded leaves.

The data pertaining to head diameter, head length, head compactness ( $Z$ value) and head weight presented in table 5 revealed significant influence of various treatments applied. Treatment $\mathrm{T}_{4}$ (VC @ 6.6t/ha $+A B+$ $\mathrm{PSB}+\mathrm{KSB}$ ) recorded significantly maximum head diameter $(6.50 \mathrm{~cm})$, head length
$(21.16 \mathrm{~cm})$, head compactness (1.89) and individual head weight $(613.33 \mathrm{~g})$ which were at par with treatment $\mathrm{T}_{5}$ (BDC @ 8.3 t/ha $+A B$ $+\mathrm{PSB}+\mathrm{KSB})$ and $\mathrm{T}_{3}(\mathrm{SM}(\mathrm{SM}) @ 16.6 \mathrm{t} / \mathrm{ha}+$ $A B+\mathrm{PSB}+\mathrm{KSB})$. The minimum head diameter $(3.40 \mathrm{~cm})$, head length $(17.5)$, head compactness in terms of $\mathrm{Z}$ value (0.86) and individual head weight $(275.00 \mathrm{~g})$ were noticed in treatment $\mathrm{T}_{6}(50 \% \mathrm{NPK}+50 \% \mathrm{FYM})$ followed by the treatment $\mathrm{T}_{1}$ (Recommended dose of fertilizers (RDF).

Putting up the various treatments into four different sets revealed that full application of nutrients given through organic manures plus biofertilizers $\left(T_{2}-T_{5}\right)$ resulted in maximum plant height, dry weight, $\mathrm{S} / \mathrm{R}$ ratio, folded leaves, head earliness (Fig. 1), fresh weight, head weight (Fig. 3), head length and diameter (Fig. 5), plant RGR, head compactness (Fig. 7) followed by the nutrients applied as half through inorganic fertilizers and half through organic manures plus biofertilizers $\left(T_{10}-T_{13}\right)$ against the poor values of these attributes when half of the nutrients given through inorganic fertilizers and half through organic manures $\left(\mathrm{T}_{6}-\mathrm{T}_{9}\right)$.

Further, if we consider the source of organic nutrients (Fig 2, 4 and 6) it can be stated in general that $\mathrm{VC}$ resulted in maximum plant growth and head quality followed by BDC, SM and FYM.

Considerable increase in plant height, fresh weight as well as dry weight due to different organic manures over the use of inorganic form of nutrients has also been reported through earlier workers (Pant et al., 2009; Rai et al., 2013; Getnet and Raja, 2013; Joshi et al., (2014); Eswaran and Mariselvi (2016); Islam et al., (2017). The increased plant height and weight (fresh and dry) of Chinese cabbage due to organic sources of nutrients might have resulted from the increased rate of plant growth in terms of RGR (in the present study). 
Table.1 Effect of different sources of nutrients and biofertilizers on plant height in Chinese cabbage cv. 'Solan Band Chinese Sarson'

\begin{tabular}{|c|c|c|c|c|}
\hline \multirow[t]{2}{*}{ Treatment combinations } & \multicolumn{4}{|c|}{ Plant height (cm) } \\
\hline & 15 DAT & 30 DAT & 45 DAT & $60 \mathrm{DAT}$ \\
\hline RDF (NPK @ 100:50:30 kg/ha) - T & 9.66 & 14.90 & 20.57 & 25.00 \\
\hline FYM @ 20t/ha + AB + PSB + KSB - T & 13.66 & 19.00 & 23.17 & 29.33 \\
\hline $\mathrm{SM} @ 16.6 \mathrm{t} / \mathrm{ha}+A B+\mathrm{PSB}+\mathrm{KSB}-\mathrm{T}_{3}$ & 14.00 & 19.07 & 23.90 & 29.67 \\
\hline $\mathrm{VC} @ 6.6 \mathrm{t} / \mathrm{ha}+A B+\mathrm{PSB}+\mathrm{KSB}-\mathrm{T}_{4}$ & 15.33 & 20.30 & 24.23 & 30.33 \\
\hline $\mathrm{BDC} @ 8.3 \mathrm{t} / \mathrm{ha}+A B+\mathrm{PSB}+\mathrm{KSB}-\mathrm{T}_{5}$ & 15.00 & 20.30 & 20.67 & 30.00 \\
\hline $50 \% \mathrm{NPK}+50 \% \mathrm{FYM}-\mathrm{T}_{6}$ & 9.66 & 14.83 & 19.73 & 22.67 \\
\hline $50 \% \mathrm{NPK}+\mathbf{5 0 \% \mathrm { VC } - \mathrm { T } _ { 7 }}$ & 11.00 & 16.67 & 20.93 & 26.33 \\
\hline $50 \% \mathrm{NPK}+\mathbf{5 0} \% \mathrm{SM}-\mathrm{T}_{8}$ & 10.33 & 15.56 & 20.80 & 26.00 \\
\hline $50 \% \mathrm{NPK}+50 \% \mathrm{BDC}-\mathrm{T}_{9}$ & 10.66 & 16.33 & 20.83 & 26.00 \\
\hline $50 \% \mathrm{NPK}+50 \% \mathrm{FYM}+A B+\mathrm{PSB}+\mathrm{KSB}-\mathrm{T}_{10}$ & 11.66 & 17.90 & 21.73 & 26.33 \\
\hline $50 \% \mathrm{NPK}+50 \% \mathrm{VC}+A B+\mathrm{PSB}+\mathrm{KSB}-\mathrm{T}_{11}$ & 13.66 & 18.67 & 22.83 & 29.00 \\
\hline $50 \% \mathrm{NPK}+50 \% \mathrm{SM}+A B+\mathrm{PSB}+\mathrm{KSB}-\mathrm{T}_{12}$ & 12.00 & 18.67 & 21.73 & 27.00 \\
\hline $50 \% \mathrm{NPK}+50 \% \mathrm{BDC}+A B+\mathrm{PSB}+\mathrm{KSB}-\mathrm{T}_{13}$ & 12.66 & 18.67 & 22.83 & 27.00 \\
\hline$C D(p \leq 0.05)$ & 2.071 & 1.79 & 1.94 & 3.58 \\
\hline
\end{tabular}

Table.2 Effect of different sources of nutrients and biofertilizers on fresh and dry weight in Chinese cabbage cv. 'Solan Band Chinese Sarson'

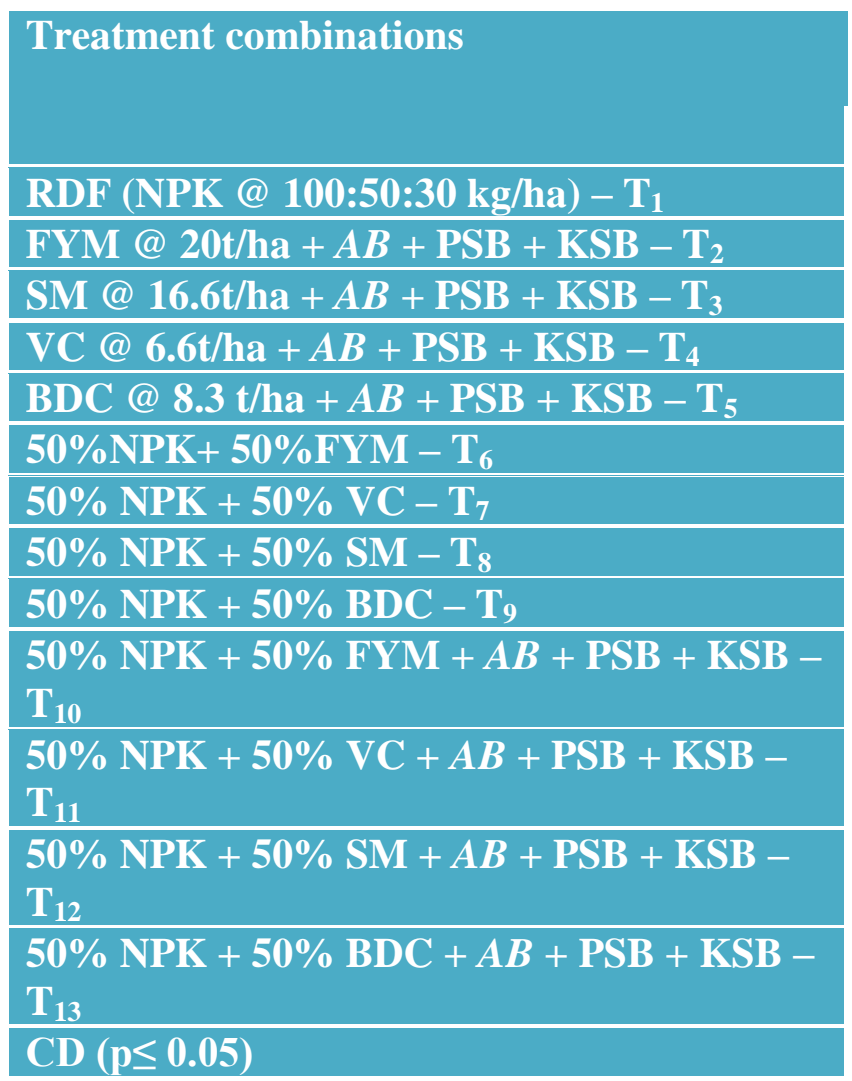

\begin{tabular}{|l|l|l|l|l|l|l|l|}
\hline \multicolumn{3}{|c|}{$\begin{array}{l}\text { Fresh weight (g/plant) } \\
\text { Days after transplanting }\end{array}$} & \multicolumn{3}{|c|}{ Dry weight (g/plant) } \\
\hline $\mathbf{1 5}$ & $\mathbf{3 0}$ & $\mathbf{4 5}$ & $\mathbf{6 0}$ & $\mathbf{1 5}$ & $\mathbf{3 0}$ & $\mathbf{4 5}$ & $\mathbf{6 0}$ \\
\hline 17.1 & 88.12 & 327.7 & 615.0 & 1.9 & 6.7 & 28.9 & 38.3 \\
\hline 29.6 & 147.1 & 553.3 & 940.0 & 3.2 & 12.5 & 37.5 & 55.3 \\
\hline 31.0 & 155.7 & 559.7 & 943.3 & 4.0 & 12.6 & 41.2 & 62.4 \\
\hline 36.2 & 220.8 & 570.7 & 1170.0 & 4.9 & 16.1 & 42.8 & 65.4 \\
\hline 32.4 & 171.7 & 560.0 & 1146.7 & 4.6 & 13.2 & 42.3 & 64.4 \\
\hline 16.9 & 85.1 & 184.3 & 578.3 & 1.9 & 5.9 & 27.1 & 31.6 \\
\hline 19.8 & 98.6 & 410.0 & 645.0 & 2.1 & 8.6 & 30.5 & 49.4 \\
\hline 18.5 & 91.8 & 374.0 & 628.3 & 2.0 & 7.5 & 29.3 & 43.3 \\
\hline 19.5 & 98.2 & 388.3 & 630.0 & 2.0 & 7.7 & 30.4 & 44.6 \\
\hline 24.0 & 99.7 & 427.7 & 681.7 & 2.5 & 8.9 & 32.6 & 51.7 \\
\hline 29.4 & 130.5 & 525.0 & 851.7 & 2.9 & 11.9 & 37.3 & 53.5 \\
\hline 28.4 & 101.1 & 433.3 & 695.0 & 2.5 & 10.8 & 33.4 & 52.4 \\
\hline 29.3 & 119.1 & 503.3 & 740.0 & 2.9 & 11.3 & 36.1 & 52.7 \\
\hline $\mathbf{2 . 0 0}$ & $\mathbf{2 6 . 0 0}$ & $\mathbf{2 7 . 3 6}$ & $\mathbf{1 0 1 . 7}$ & $\mathbf{1 . 0}$ & $\mathbf{1 . 5}$ & $\mathbf{1 . 3}$ & $\mathbf{0 . 9 7}$ \\
\hline
\end{tabular}


Table.3 Effect of different sources of nutrients and biofertilizers on shoot dry weight to root dry weight (S/R) ratio of Chinese cabbage cv. 'Solan Band Chinese Sarson' at different days after transplanting (DAT)

\begin{tabular}{|l|l|}
\hline Symbol Treatment combination detail \\
\hline RDF (NPK@ $100: 50: 30 \mathrm{~kg} / \mathrm{ha})-\mathrm{T}_{1}$ \\
\hline FYM @ 20t/ha + AB + PSB + KSB $-\mathrm{T}_{2}$ \\
\hline SM@ $16.6 \mathrm{t} / \mathrm{ha}+A B+\mathrm{PSB}+\mathrm{KSB}-\mathrm{T}_{3}$ \\
\hline $\mathrm{VC} @ 6.6 \mathrm{t} / \mathrm{ha}+A B+\mathrm{PSB}+\mathrm{KSB}-\mathrm{T}_{4}$ \\
\hline $\mathrm{BDC} @ 8.3 \mathrm{t} / \mathrm{ha}+A B+\mathrm{PSB}+\mathrm{KSB}-\mathrm{T}_{5}$ \\
\hline $50 \% \mathrm{NPK}+50 \% \mathrm{FM}-\mathrm{T}_{6}$ \\
\hline $50 \% \mathrm{NPK}+50 \% \mathrm{VC}-\mathrm{T}_{7}$ \\
\hline $50 \% \mathrm{NPK}+50 \% \mathrm{SM}-\mathrm{T}_{8}$ \\
\hline $50 \% \mathrm{NPK}+50 \% \mathrm{BDC}-\mathrm{T}_{9}$ \\
\hline $50 \% \mathrm{NPK}+50 \% \mathrm{FYM}+A B+\mathrm{PSB}+\mathrm{KSB}-$ \\
$\mathrm{T} 10$ \\
\hline $50 \% \mathrm{NPK}+50 \% \mathrm{VC}+A B+\mathrm{PSB}+\mathrm{KSB}-\mathrm{T}_{11}$ \\
\hline $50 \% \mathrm{NPK}+50 \% \mathrm{SM}+A B+\mathrm{PSB}+\mathrm{KSB}-\mathrm{T}_{12}$ \\
\hline $50 \% \mathrm{NPK}+50 \% \mathrm{BDC}+A B+\mathrm{PSB}+\mathrm{KSB}-\mathrm{T}_{13}$ \\
\hline $\mathrm{CD}(\mathrm{p} \leq 0.05)$ \\
\hline
\end{tabular}

\begin{tabular}{|l|l|l|l|}
\hline \multicolumn{4}{|c|}{$\begin{array}{c}\text { Shoot dry weight to root dry weight } \\
\text { ratio }\end{array}$} \\
\hline 15 DAR
\end{tabular}

Table.4 Effect of different sources of nutrients and biofertilizers on plant RGR and folded versus unfolded leaves in Chinese cabbage cv. 'Solan Band Chinese Sarson'

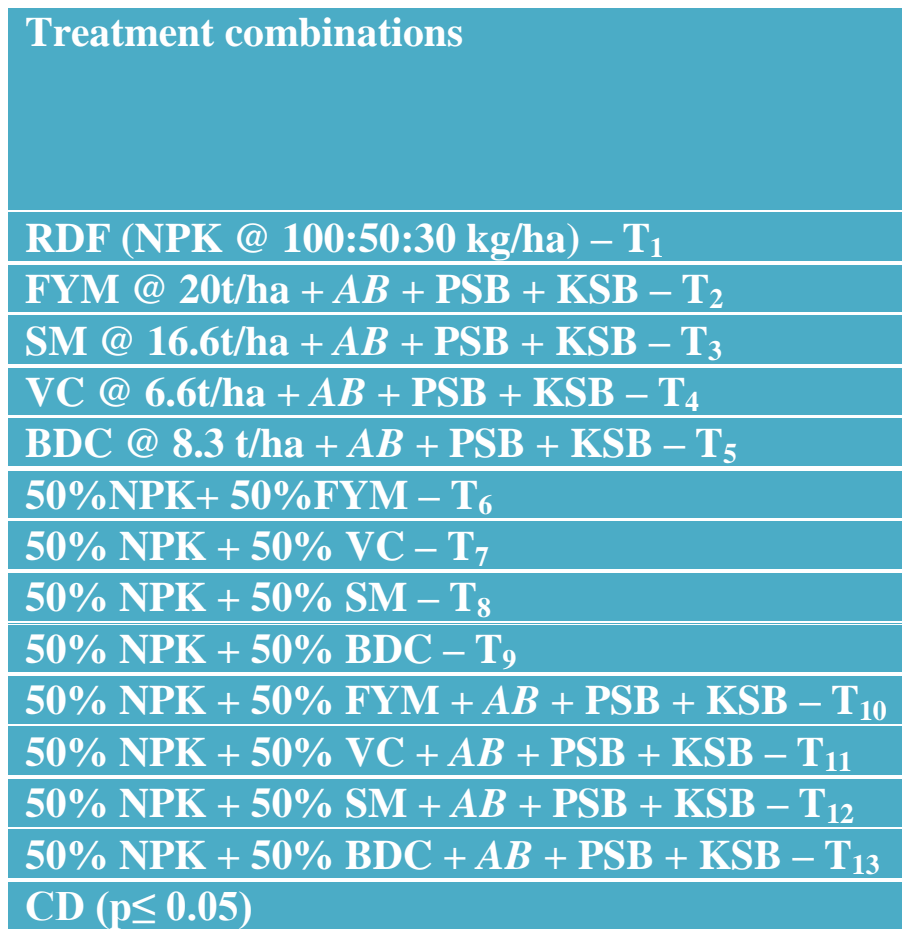

\begin{tabular}{|c|c|c|c|c|}
\hline $\begin{array}{c}\text { RGR } \\
(\mathrm{g} / \mathrm{g} / \mathrm{day})\end{array}$ & $\begin{array}{c}\text { Head Initiation } \\
\text { (day) }\end{array}$ & \multicolumn{2}{|c|}{ Leaves/ plant } \\
\hline $\mathbf{0 - 3 0}$ & $\mathbf{3 0 - 6 0}$ & & Folded & Unfloded \\
\hline DAT & DAT & & & \\
\hline 0.12 & 0.28 & 22.33 & 25.00 & 09.00 \\
\hline 0.89 & 0.64 & 19.66 & 29.33 & 13.00 \\
\hline 0.93 & 0.65 & 19.66 & 29.67 & 13.00 \\
\hline 0.97 & 0.74 & 19.33 & 31.33 & 13.33 \\
\hline 0.94 & 0.72 & 19.66 & 30.00 & 13.00 \\
\hline 0.10 & 0.30 & 23.00 & 22.67 & 09.00 \\
\hline 0.74 & 0.54 & 21.66 & 26.33 & 10.33 \\
\hline 0.54 & 0.60 & 21.66 & 26.00 & 09.33 \\
\hline 0.66 & 0.47 & 21.66 & 26.00 & 09.66 \\
\hline 0.77 & 0.53 & 21.00 & 26.33 & 11.66 \\
\hline 0.84 & 0.45 & 20.00 & 29.00 & 12.66 \\
\hline 0.80 & 0.48 & 20.66 & 27.00 & 12.00 \\
\hline 0.81 & 0.52 & 20.33 & 27.00 & 12.66 \\
\hline $\mathbf{0 . 2 9}$ & $\mathbf{0 . 0 6}$ & $\mathbf{1 . 2 5 1}$ & $\mathbf{3 . 5 8}$ & $\mathbf{2 . 9 2}$ \\
\hline
\end{tabular}


Table.5 Effect of different sources of nutrients and biofertilizers on head physical quality in Chinese cabbage cv. 'Solan Band Chinese Sarson'

\begin{tabular}{l} 
Treatment \\
\hline RDF (NPK@ $100: 50: 30 \mathrm{~kg} / \mathrm{ha})-\mathrm{T}_{1}$ \\
\hline FYM @ 20t/ha + AB + PSB + KSB $-\mathrm{T}_{2}$ \\
\hline $\mathrm{SM} @ 16.6 \mathrm{t} / \mathrm{ha}+\mathrm{AB}+\mathrm{PSB}+\mathrm{KSB}-\mathrm{T}_{3}$ \\
\hline $\mathrm{VC} @ 6.6 \mathrm{t} / \mathrm{ha}+\mathrm{AB}+\mathrm{PSB}+\mathrm{KSB}-\mathrm{T}_{4}$ \\
\hline $\mathrm{BDC} @ 8.3 \mathrm{t} / \mathrm{ha}+\mathrm{AB}+\mathrm{PSB}+\mathrm{KSB}-\mathrm{T}_{5}$ \\
\hline $50 \% \mathrm{NPK}+50 \% \mathrm{FYM}-\mathrm{T}_{6}$ \\
\hline $50 \% \mathrm{NPK}+50 \% \mathrm{VC}-\mathrm{T}_{7}$ \\
\hline $50 \% \mathrm{NPK}+50 \% \mathrm{SM}-\mathrm{T}_{8}$ \\
\hline $50 \% \mathrm{NPK}+50 \% \mathrm{BDC}-\mathrm{T}_{9}$ \\
\hline $50 \% \mathrm{NPK}+50 \% \mathrm{FYM}+A B+\mathrm{PSB}+\mathrm{KSB}-\mathrm{T}_{10}$ \\
\hline $50 \% \mathrm{NPK}+50 \% \mathrm{VC}+A B+\mathrm{PSB}+\mathrm{KSB}-\mathrm{T}_{11}$ \\
\hline $50 \% \mathrm{NPK}+50 \% \mathrm{SM}+A B+\mathrm{PSB}+\mathrm{KSB}-\mathrm{T}_{12}$ \\
\hline $50 \% \mathrm{NPK}+50 \% \mathrm{BDC}+A B+\mathrm{PSB}+\mathrm{KSB}-\mathrm{T}_{13}$ \\
\hline $\mathrm{CD}(\mathrm{p} \leq 0.05)$ \\
\hline
\end{tabular}

\begin{tabular}{|c|c|c|c|}
\hline \multicolumn{4}{|c|}{ Physical Quality of Head } \\
\hline Diameter & $\begin{array}{l}\text { Length } \\
\text { (cm) }\end{array}$ & $\begin{array}{l}\text { Weight } \\
\text { (g/head) }\end{array}$ & $\begin{array}{l}\text { Z } \\
\text { value }\end{array}$ \\
\hline 4.63 & 17.83 & 323.33 & 0.90 \\
\hline 5.46 & 19.00 & 470.00 & 1.51 \\
\hline 5.63 & 19.33 & 505.00 & 1.53 \\
\hline 6.50 & 21.16 & 613.33 & 1.89 \\
\hline 5.83 & 20.33 & 598.33 & 1.78 \\
\hline 3.40 & 17.50 & 275.00 & 0.86 \\
\hline 5.20 & 18.16 & 371.66 & 1.08 \\
\hline 4.66 & 18.00 & 358.33 & 0.94 \\
\hline 4.83 & 18.00 & 363.33 & 1.01 \\
\hline 5.20 & 18.16 & 391.66 & 1.16 \\
\hline 5.33 & 18.16 & 440.00 & 1.23 \\
\hline 5.23 & 18.33 & 395.00 & 1.16 \\
\hline 5.26 & 18.66 & 398.33 & 1.23 \\
\hline $\mathbf{0 . 9 6}$ & $\mathbf{1 . 3 1}$ & $\mathbf{4 7 . 7 9}$ & $\mathbf{0 . 1 1}$ \\
\hline
\end{tabular}

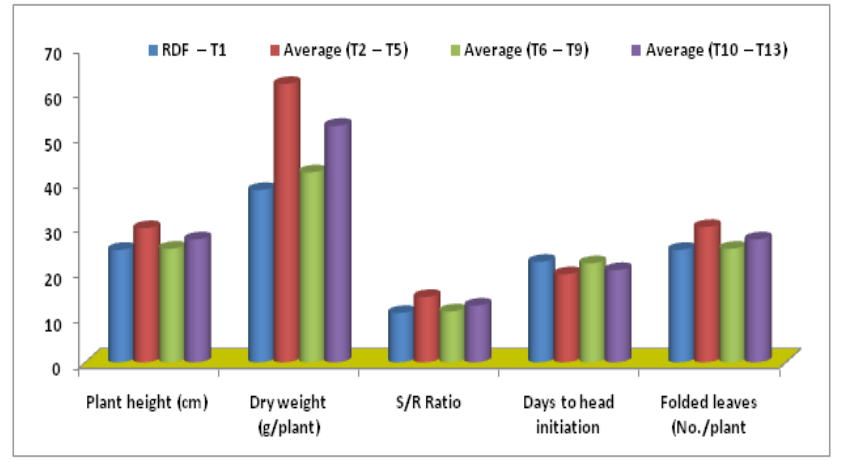

Fig.1 Effect of different set of organic amendments on plant growth and head formation in Chinese cabbage

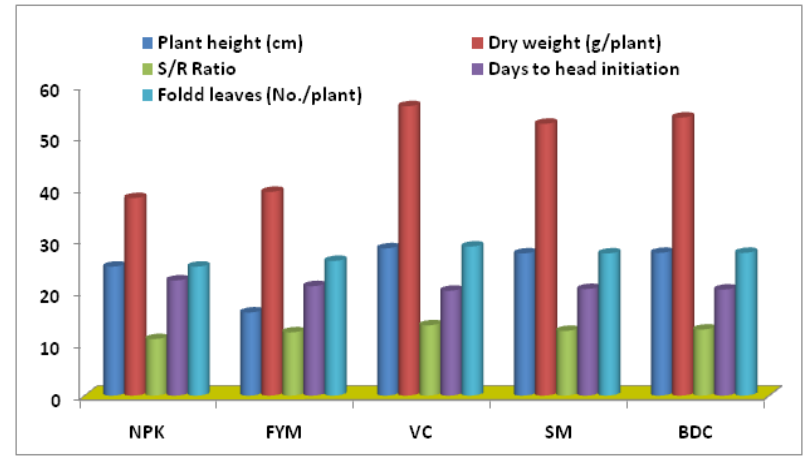

Fig.2 Effect of individual organic supplements on plant growth and head formation in Chinese cabbage 


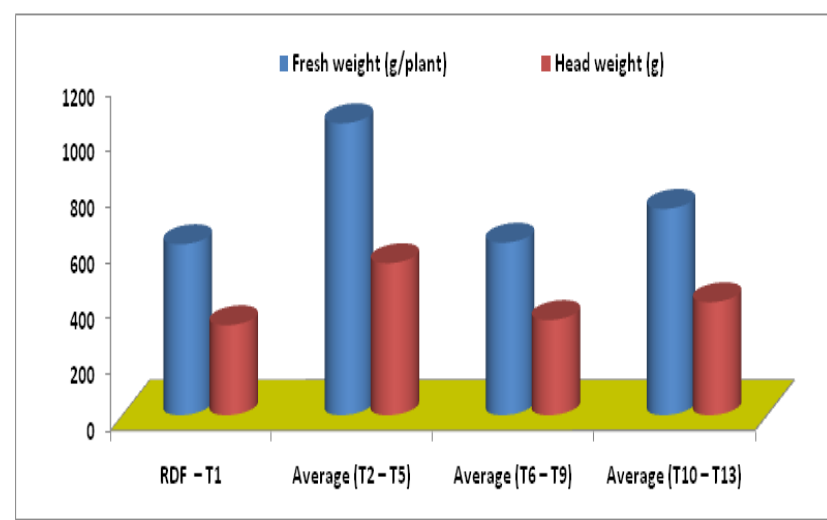

Fig.3 Effect of different set of organic amendments on fresh plant as well as head weight in Chinese cabbage

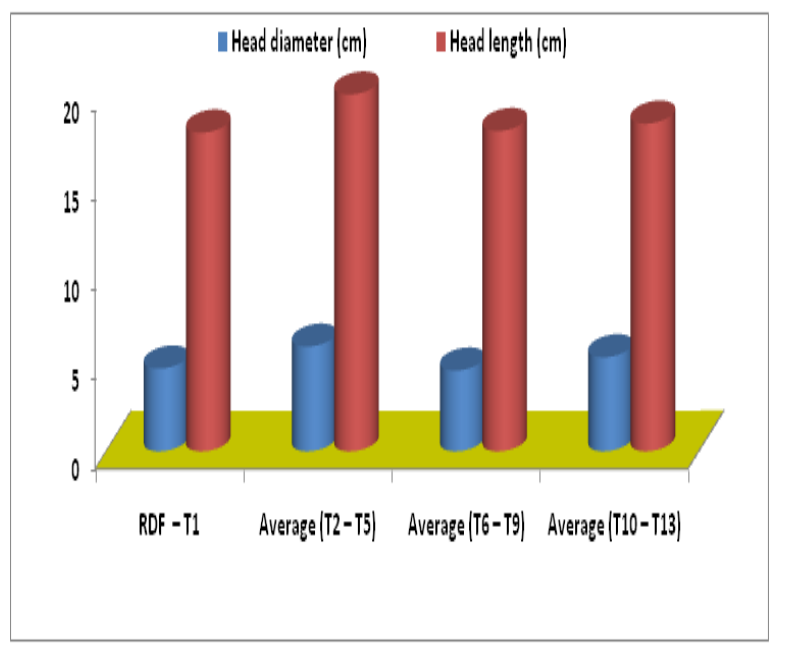

Fig.5 Effect of different set of organic amendments on head size (diameter and length) in Chinese cabbage

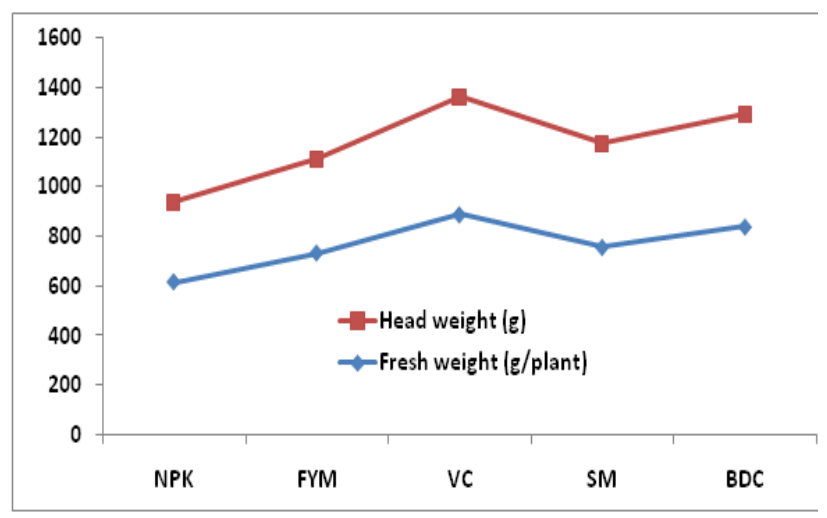

Fig.4 Effect of individual organic supplements on plant head fresh weight in Chinese cabbage

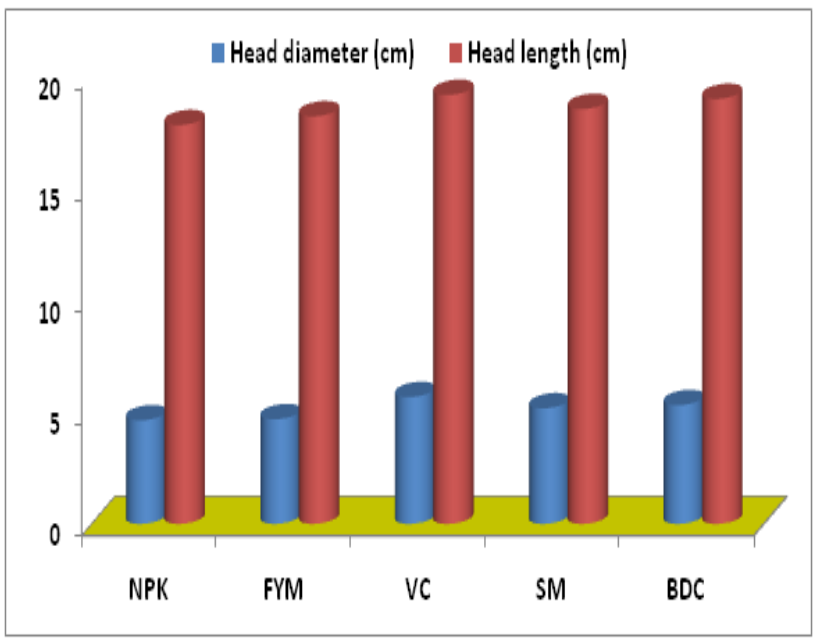

Fig.6 Effect of individual organic supplements on head diameter and length in Chinese cabbage

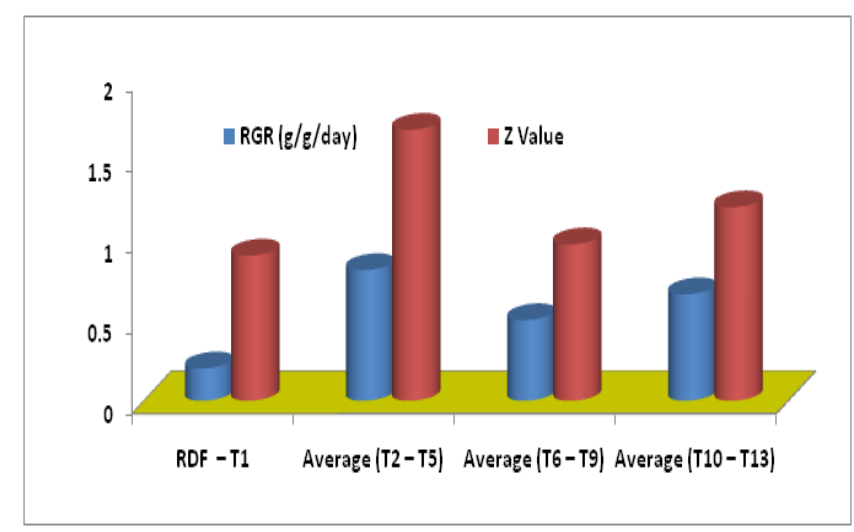

Fig.7 Effect of different set of organic amendments on plant RGR and head compactness in Chinese cabbage 
The highest increase in plant growth of Chinese cabbage under VC treatment may be attributed to its ability to increase nutrient availability through mineralization and humification (Albanell et al., 1988), improve soil health (Edwards and Burrows 1988) and availability of various microbiota particularly fungi, bacteria and actinomycetes which makes it suitable for plant growth (Tomati et al., 1987). Further, increase in plant growth due to addition of biofertilizers namely PSB and KSB is obvious due to increased availability of major nutrients. Improved S/R ratio indicates that organic source of nutrients especially, VC has encouraged both root and shoot growth but shoot growth was more responsive than root growth. Our results corroborates with previous works (Xu and Mou, 2016). Kollar et al., (1970) reported that an increase in RGR was the result of greater demand for assimilated in rapidly growing crop. Superiority of VC followed by FYM for accelerating the growth rate in terms of RGR has also been fixed by Sallaku et al., (2009). In line with results regarding days taken to head initiation earlier workers also reported that high fertility levels and organic manure favors an early head initiation and maturity in cabbage (Wolde, 2015).

So far as head quality and yield in terms of length, breadth, compactness and weight is concerned our results confirm the reports notified by earlier workers (Haque et al., 2015). In line with our results regarding superiority of VC, Chatterjee et al., (2012) also found that $\mathrm{VC}$ was better source of nutrient than FYM. Greater head size and weight with the application of VC might be due to the supply of all essential nutrients and soil porosity as compared to other organic manures which provided favorable environment to

Finally, in light of the findings of the present study it may be concluded that recommended doses of nutrients (NPK @ 100:50:30 kg/ha) vermicompost along with biofertilizers (Azotobacter + PSB + KSB) should be applied on nitrogen equivalent basis to promote the plant growth and get the better head yield in Chinese cabbage.

\section{Acknowledgement}

Authors are thankful to the Head of Division (Vegetable Science) and Dean, Faculty of Horticulture for providing technical as well as financial support to carryout this programme.

\section{References}

Albanell, E., Plaixats. J. an Cabrero, T. 1988. Chemical changes during vermicomposting (Eisenia fetida) of sheep manure mixed with cotton industrial wastes. Biol. Fertil. Soils 6:266-269

Bahadur, A., Singh, J., Singh, K. P., Upadhay, A. K. and Rai, M. 2006. Effect of organic amendments and biofertilizers on growth, yield and quality attributes of Chinese cabbage (Brassica pekinensis). Indian J. Agri. Sci. 76: 596608.

Chatterjee, R., Jana, J. C. and Paul, P. K. 2012. Enhancement of head yield and quality of cabbage (Brassica oleracea) by combining different sources of nutrients. Indian J. Agri. Sci. 82 (4): 324-328.

Edwards, C. A. and Burrows, I. 1988. The potential of earthworm composts as plant growth media. In: Edwards, C. A., Neuhauser, S.P.B (eds) Earthworms in Environmental and Waste Management. Academic Publishing. b.v. The Netherlands, pp. 211-220.

Eswaran, N. and Mariselvi, S. 2016. Efficacy of vermicompost on growth and yield parameters of Lycopersicum esculentum 
(Tomato). Int. J. Sci. and Res. Publ. 6 (1): $95-108$.

Getnet, M. and Raja, N. 2013. Impact of vermicompost on growth and development of cabbage, Brassica oleracea Linn. and their sucking pest, Brevicoryne brassicae Linn. (Homoptera: Aphididae). Res. J. Env.Earth Sci. 5(3): 104-112.

Haque, A., Bhowal, S. K., Ali, M. and Robbani, M. 2015. Yield and yield attributes of cabbage (Brassica oleracea var. capatata L.) as influenced by soil organic amendments. Basic Res. J. Agri. Sci. Rev. 4(12): 339-344.

Hoffmann, W. A. and Poorter, H. 2002. Avoiding bias in calculations of relative growth rate. Ann. Bot. 90 (1): 37-42.

Hunt, R. 1978. Plant growth analyses. Institute of Biology No. 96, London

Islam, M. A., Ferdous, G., Akter, A., Hossain, M. M. and Nandwani D. 2017. Effect of organic, inorganic fertilizers and plant spacing on the growth and yield of cabbage. Agriculture (MDPI), 7 (31): (doi:10.3390/agriculture7040031)

Islam, M. S. and Haque, M. A. 1992. Soil and fertilizer management for vegetables. Proceedings of national review and planning workshop. 26-29 January, 1992. BARI Joydebpur, Gazipur, Bangladesh.

Joshi, R., Singh, J. and Vig, A. P. 2014. Vermicompost as an effective organic fertilizer and biocontrol agent: effect on growth, yield and quality of plants. Rev Environ Sci Biotechnol 13 (3) - DOI 10.1007/s11157-014-9347-1

Kollar, H. R., Myquistand, W.E., and Chorash, I. S. 1970 Growth analysis of soybean community. Crop Sci. 10: 407412.

Pant, A. P., Radovich, T. J. K., Hue, N. V., Talcott, S. T., Krenek, K. A. 2009. Vermicompost extracts influence growth, mineral nutrients, phytonutrients and antioxidant activity in pak choi (Brassica rapa cv. Bonsai, chinensis group) grown under vermicompost and chemical fertilizer. $J$. Sci. Food Agric. 89(14):2383-2392

Pearson, O. H. 1931. Methods for determining the solidarity of cabbage heads. Hilgardia 5: $383-393$.

Rai, R., Thapa, U., Mandal, A.R., Roy, B. 2013. Growth, yield and quality of cabbage (Brassica oleracea var capitata L.) as influenced by vermicompost. Env. Ecol., 31, 314-317

Raja, G. and Veerakumari, L. 2013. Influence of vermicompost on the yield and alkaloid content of Withania somnifera Dunal. Int. J. Adv. Biol. Res., 3 (2): 223226

Rashid, M. M. 1999. Sabjii biggam. Rashid publishing House 94-old DOHS Dhaka1206.p. 248

Sallaku, G., Babaj, I., Kaciu, S., Balliu, A. 2009. The influence of vermicompost on plant growth characteristics of cucumber (Cucumis sativus L.) seedlings under saline conditions. $J$. Food Agric. Env.., 7(3-4): 869-872.

Singh, J., Upadhayay, A. K., Bahadur, A. and Singh, K. P. 2004. Dietary antioxidants and minerals in crucifers. J. Veg. Crop Prod. 10: 33-41.

Tiwari M. 2015. Effect of organic, Inorganic and biofertilizers on growth and yield of Tomato (Lycopersicon esculentum Mill) under protected condition. Thesis submitted to Jawaharlal Nehru Krishi Vishwa Vidyalaya, Jabalpur In partial fulfillment of the requirements for the Degree of Master of Science in Agriculture (Horticulture)

Tomati, U., A. Grappelli and E. Galli. 1987. The presence of growth regulators in earthworm-worked wastes. In: Bonvicini Paglioi, A.M. and P. Omodeo (eds) On Earthworms. Proceedings of International Symposium on 
Earthworms. Selected Symposia and Monographs, Unione Zoologica Italiana, 2, Mucchi, Modena, pp. 423435.

Wolde, S. T. 2015. Response of head cabbage (Brassica oleracea L.) to different rates of nitrogen fertilizer and farmyard manure at Bore, Southern Ethopia. A
Thesis Submitted to the School of Plant Science, School of Graduate Studies, Haramaya University, Haramaya.

$\mathrm{Xu}, \mathrm{C}$. and Mou, B. 2016. Vermicompost affects soil properties and spinach growth, physiology, and nutritional value. HortSci. 51(7):847- 855.

\section{How to cite this article:}

Sumati Narayan, Arief Ibrahim, Farooq Ahmad Khan, Khursheed Hussain, Ajaz Ahmad Malik, Shakeel Ahmad Mir and Raj Narayan. 2018. Organic Nutrient Management for Improved Plant Growth and Head Yield of Chinese Cabbage (Brassica rapa L. var pekinensis). Int.J.Curr.Microbiol.App.Sci. 7(09): 3049-3059. doi: https://doi.org/10.20546/ijcmas.2018.709.380 